\title{
The role of collaboration and external knowledge for innovation in small food firms
}

\author{
Sofia Wixe ${ }^{1}$ (D) Pia Nilsson ${ }^{1,2} \cdot$ Lucia Naldi $^{1,3} \cdot$ Hans Westlund $^{1,4}$
}

Received: 14 December 2020 / Accepted: 21 October 2021 / Published online: 9 November 2021

(c) The Author(s) 2021, corrected publication 2021

\begin{abstract}
In this study, we use unique purpose-built survey data to show that small food firms are more innovative when externally engaged. To capture this, we apply a broad classification of innovative activities, including new products, processes, markets, organization, and distribution channels, and examine them against types of external interactions. The analysis, an ordered logit estimation, controls for heterogeneity across firms as well as geographic conditions. The results demonstrate a positive relationship between external interaction and firm innovation, though there are differences across types of external engagement and innovation activities. Product innovation benefits from knowledge from extra-regional firms, while several of the other forms of innovation show a positive relationship with support from regional and municipality boards. Additionally, firm collaboration regarding transports and sales enhances most types of innovation, but there are few relationships of benefit with research-intensive organizations. We conclude that, to be effective, innovation strategies of both the firms themselves and policymakers need to consider local context, access to intra- and extra-regional knowledge sources, and what types of innovation activities the firms are engaged in.
\end{abstract}

JEL Classification $\mathrm{L} 66 \cdot \mathrm{O} 36 \cdot \mathrm{R} 30$

Sofia Wixe

sofia.wixe@ju.se

1 Centre for Entrepreneurship and Spatial Economics (CEnSE), Jönköping International Business

School, P.O. Box 1026, 55111 Jönköping, Sweden

2 Department of Economics, Swedish University of Agricultural Sciences, Uppsala, Sweden

3 Centre for Family Enterprise and Ownership (CeFEO), Jönköping International Business School, Jönköping, Sweden

4 Urban and Regional Studies, KTH Royal Institute of Technology, Stockholm, Sweden 


\section{Introduction}

Traditionally, research on innovation and its determinants has focused on high-tech industries, and thus on firms that are well endowed with internal knowledge, such as high research intensity and highly skilled labor (Vrontis et al. 2017). But along with the awareness that innovation is critical for the competitiveness of firms in all sectors and in all sizes, there is increasing evidence that innovation in small and specialized firms in low-tech industries ${ }^{1}$ is especially enabled by accessing external knowledge through collaborations and networking activities (Bresciani 2017; Galeti et al. 2016). Nijkamp et al. (2007) argue that the networking capabilities of firms, along with their learning capacities, are the main driver of innovation. External interactions can also be seen from a geographic perspective, where both local knowledge spillovers and networks reaching across space matter for innovation capacity (Baycan et al. 2017; Karlsson et al. 2014).

Some studies have focused on the food industry specifically and confirmed the relevance of collaboration and externally sourced knowledge for innovation. Karantininis et al. (2010) find that network links, measured as actual contracts with suppliers and customers, increase innovation in the Danish food industry. McAdam et al. (2014) explore the longitudinal development of horizontal innovation networks within the UK SME agri-food sector. Additionally, Maietta (2015) and Maietta et al. (2017) examine collaboration and innovation in the European and Italian food industry, respectively, although the focus of these studies is solely on collaboration with universities. In a qualitative study of the Swedish food industry, McKelvey and Ljungberg (2017) find that public policy that promotes firm and university research collaboration can stimulate product and process innovation.

Despite this progress, important gaps remain in our understanding. First, while extant research has helped deepen our knowledge of the innovation benefits of specific forms of external knowledge or interrelationships, we need a broader exploration of the innovation benefits associated with different types of external engagement. As summarized by Lefebvre et al. (2015) with specific reference to low-tech sectors, "few studies have investigated the diverse sources of knowledge that firms in such sectors rely upon" (p.412). Second, scholars have criticized the restrictive conceptualizations of innovation that fail to account for the types of knowledge-based innovation in low-tech sectors (Naldi et al. 2015), and others call for "more research on the relation between inter-organizational relationships and innovation types other than product and process innovations" (Lefebvre et al. 2015: 412). In specific reference to the agri-food industry, McAdam et al. (2014) promote a more inclusive approach that considers four main types of innovation: product, process, market, and organizational. Other scholars have suggested to also include new suppliers and new distribution methods (Naldi et al. 2015). This expansion of types of innovation is in line with Schumpeter (1934), who argued that innovation should be regarded in broad terms.

\footnotetext{
${ }^{1}$ Eurostat classifies the food industry as low-technology: https://ec.europa.eu/eurostat/cache/metadata/ Annexes/htec_esms_an3.pdf.
} 
Against this background, the purpose of this study is to analyze the relationships between a wide range of external interactions and different types of innovation, based on unique survey data on small food firms in Sweden. In addition, the study takes a geographic perspective, where we test both intra- and extra-regional interactions of the firms. The paper commences with a review of the literature on external knowledge, collaboration, and innovation to identify relevant sources of external knowledge. Thereafter, we present our empirical study, which builds on the approach of Dahl Fitjar and Rodríguez-Pose (2013).

The results point in general to positive relationships between firm innovation and external interactions, be they collaborations, support from regional actors, or knowledge from intra- and extra-regional actors. Moreover, these relationships differ across the various dimensions of external interactions and innovation. The findings have two main implications for both policy and practice. First, our results support that the most effective place-based policies, especially for rural regions, involve promoting various types of collaborations. Second, we find that there is a need for innovation policies that allow for "tailor-made" solutions at the local level, considering the prerequisites of the local firms and their geography. This calls for local leadership with local knowledge. In several academic contributions (see Stough (2003), Stimson et al. (2005), Stimson et al. (2009) and Stough (2010)) Roger Stough, among others, argues that such leadership plays a key role in regional economic development and it need not necessarily be government-based.

\section{External knowledge, collaboration, and innovation}

The importance of external knowledge for firm survival and growth was acknowledged already by Marshall (1890), who argued that the co-location of firms creates external economies of scale due to pooling of skilled labor, supply-and-demand linkages, and knowledge spillovers. Duranton and Puga (2004) argue along these lines and identify matching, sharing, and learning as the micro-foundations for the so-called agglomeration economies. In their view, learning is achieved via the market effects resulting from the employment of skilled labor and linkages with suppliers and customers, and via non-market effects, such as the transfer and diffusion of knowledge and information through informal networks. In this way, both networks and collaborations with other firms along the supply chain, universities and research institutes, and development agencies provide external knowledge sources that firms can exploit in their innovation activities (Baycan et al. 2017).

The role of external engagement for innovation is commonly discussed under the framework of regional innovation systems (RIS) (see Asheim et al. (2011) for an overview). This framework builds on the ideas of Marshall and follows the literature on national innovation systems (Lundvall, 1992). It is also closely related to the literature on clusters (Porter 1990) and so-called open innovation (Chesbrough, 2003). Several studies provide empirical support that external interactions enhance firm innovation, for example Feldman (1994) and Caloghirou et al. (2004). Both the RIS and the open innovation framework involve a variety of (external) actors across the public and private sectors, including other firms, research institutes and universities, 
organizations for skills competence and business development, as well as regional governments. Baycan and Stough (2013) highlight the increased importance of universities in fostering innovation processes, but acknowledge differences in values, interests, and culture between academic and commercial organizations.

Previous empirical studies typically focus on just one or a few types of external engagement. An exception is Jensen et al. (2007), who distinguish between the Science, Technology and Innovation (STI) mode, and the Doing, Using and Interacting (DUI) mode. STI focuses on the use of codified scientific knowledge for learning and innovation, including R\&D laboratories, universities, and research centers, while DUI refers to informal or tacit knowledge gained through experiences and learning-by-doing. ${ }^{2}$ Using Danish data, Jensen et al. (2007) show that employing either of the modes increases the likelihood that a firm is innovative. Dahl Fitjar and Rodríguez-Pose (2013) also classify collaborations with universities, research institutes, and consultancies as STI modes of interaction, while collaborations with suppliers, customers, and competitors are classified as DUI modes. Using data for Norway, Dahl Fitjar and Rodríguez-Pose (2013) find that collaboration with universities and research institutes, as well as suppliers, increases the likelihood of both product and process innovation, whereas collaboration with customers is positively related to product innovation only.

Collaboration with external actors is shown to be particularly important for small- and medium-sized firms (SMEs) (Rothwell 1991; Edwards et al. 2005; Spithoven et al. 2013). Access to external knowledge through collaborations should thus be an important factor that influences the survival and growth of local food producers, as they tend to be small and specialized. Cooke and Morgan (1998) argue along these lines and maintain that the potential of SMEs to innovate is related to their engagement in learning networks. Freel (2000) identifies four barriers to innovation for small firms: i) limited access to finance; ii) poor management and marketing skills; iii) lack of skilled labor; and iv) costly and/or misdirected information search activities. Smallbone et al. (2003) point to additional challenges for SMEs due to their distinctive organizational cultures usually resulting from a combination of ownership and management as well as family ties, along with having less influence over their external environment than larger firms. Hence, SMEs commonly lack the necessary internal financial resources for R\&D and highly skilled labor, both of which are important capabilities for innovation. Additionally, food firms operate in low-technology, often rural, settings, which further hampers their ability to employ highly educated and productive workers due to sectoral and spatial sorting (Edwards et al. 2009; Andersson et al. 2014). The implication is that networks and cooperation between firms, as well as between firms and other actors in the private and public sector, offer greater potential to provide the necessary support systems for these firms to engage in innovation activities.

The importance of external relations for innovation in SMEs is confirmed by several empirical studies (see Cumbers et al. (2003), de Jong and Vermeulen (2006), Lee et al. (2010), Zeng et al. (2010)). Based on the previous literature and empirical

\footnotetext{
${ }^{2}$ The literature on learning-by-doing dates back to Arrow (1962).
} 
results for European regions, Tödtling and Kaufmann (2001) find that collaborations with customers and suppliers, that is, DUI partners, are of particular importance for innovation in SMEs. This is likely explained by weak links and cultural barriers between SMEs and research institutes and universities. Maietta (2015) find that small firms in remote locations especially face difficulties in finding public R\&D partners. Additionally, Maietta et al. (2017) find that the presence of large research organizations may harm collaboration and innovation in the food industry. Further empirical studies confirm the importance of supplier and customer collaborations for innovation in SMEs in general (Nieto and Santamaría 2010) and in the agri-food sector in particular (Stewart-Knox and Mitchell 2003; Gellynck and Kühne 2008; Capitanio et al. 2009; Karantininis et al. 2010).

Regarding the geographic dimension of external engagements, results from several European projects show that while national and international networks are important for large firms, the most relevant space for interactions for SMEs is usually their region (Tödtling and Kaufmann 2001). This is consistent with the STI/ DUI framework and the empirical results, showing that DUI partners are particularly important for SMEs. As mentioned above, DUI learning is based on tacit knowledge, while STI learning is based on codified knowledge. This supports the notion that that geographic proximity is likely to be more relevant for DUI interactions. Still, Dahl Fitjar and Rodríguez-Pose (2013) find that it is non-regional supply chain interactions that enhance both product and process innovation. Similar results for Swedish firms are found by Bjerke and Johansson (2015). Small local food producers are commonly located in sparsely populated rural regions, which are characterized by lower access to market potential as well as knowledge resources, such as highly educated employees and research centers, compared to urban regions (Tödtling and Tripp, 2005; Foray 2016). It may thus be expected that extra-regional knowledge resources are of importance for these firms.

Given this literature review, it is clear that several types of external interactions are critical for innovation in small firms in low-tech industries. The types of interactions can be sorted under the DUI mode, which includes collaborations along the firm's supply chain (supplier, customers, distributors, etc.), and the STI mode, which broadly covers support from other actors (universities and research institutes, business associations and competence centers, regional boards, etc.). In addition, there is a geographic aspect, where the actor providing the external knowledge (firm, competence center, university, etc.) may be located within or beyond the regional borders.

\section{Empirical design}

\subsection{Our context}

Our choice of studying innovation among small and specialized firms in the food industry is motivated by several factors. First, this industry is fundamental to support daily human life. In most Western countries, the basic need for nutrition is, however, met and food can be considered an experience good (c.f. Nelson (1970)) 
subject to individual tastes and preferences as well as budget constraints. As such, small firm survival and competitiveness in this sector is highly dependent on different forms of innovation.

Second, sustainable local and national food production is essential to preserve natural values, such as open spaces and biodiversity. International food crises are raising the issue of national self-sufficiency in food production. Food crises increase uncertainty among consumers about the quality and safety of food, which raises the issue of asymmetric information in the food industry (Verbeke 2005). This boosts the attractiveness of locally produced food, which further supports the relevancy of studying innovation in these types of firms.

Third, innovation in the food industry plays a key role in rural development since unique and innovative local food production provides an experience good that attracts tourism (Sims 2009; Everett 2008). This brings improved employment opportunities in the food industry as well as in complementary industries. Finally, as discussed above, the focus on food firms allows for exploring drivers of innovation in a low-tech industry, which remains an under-researched topic (Lefebvre et al. 2015; Vrontis et al. 2017).

\subsection{Sample and data collection}

Given the focus of this study, we use a single-industry design and draw our sample from the entire population of food producers in Sweden (NACE rev. 2 code 10 manufacturer of food products, excluding pet food). We exclude firms with less than 1 full-time employee and with 250 or more employees. Using Amadeus, a comprehensive database of all firms in Sweden, we identify 1,782 firms.

We collected a unique dataset using both register data and survey methods. Firmlevel register data are derived from two business databases: Amadeus and Retriever. Aggregated data on the firms' neighborhood and region are collected from Statistics Sweden. For the survey, we constructed a questionnaire per established practices (Dillman et al. 2014). Trained interviewers administered the questionnaire survey via telephone to the firms' CEO or (if the CEO was not available) to a member of the firm's management team. The interviews were conducted in spring 2015 and firms located in rural regions were given priority. Surveys with complete answers on all the variables of interest are available from 416 firms, ${ }^{3}$ which represent 23.3 percent of the firms in our initial sample. Among the interviewed firms, 53.2 percent are in regions classified as rural, 29.1 percent in city regions, and 17.6 percent in metropolitan regions. However, judging from the postal addresses, many of the firms in regions classified as city or metropolitan are in sparsely populated parts of these regions, making them in effect similar in character to rural firms.

The mean size of the surveyed firms is 10.8 employees, while the median is 4.3 employees, which indicates that the final sample consists largely of small firms. Indeed, 95 percent of the interviewed firms have less than 50 employees.

\footnotetext{
${ }^{3}$ Not all variables are used in all estimations. Hence, the number of observations varies between 383 and 427 .
} 


\subsection{Variables}

To capture innovativeness of firms, there are seven dependent variables, which measure different types of innovation:

- Introduction of new goods

- Introduction of new services

- Use of new processes or production methods

- Selling to new markets

- Use of new suppliers

- New ways of organization

- New ways of distribution

All dependent variables are measured on an ordinal scale with five categories, ranging from 0 (no new) to 4 (many new).

The explanatory variables of main interest concern collaboration with other firms (DUI mode), support from regional actors (mainly STI mode), and the geographic dimension of external knowledge. Collaboration is measured as to what extent the firms engage in collaboration with other actors in the region, regarding:

- Transports

- Purchases

- Production

- Marketing

- Sales

- Product development

Collaboration is measured on an ordinal scale with five categories, ranging from 0 (no collaboration) to 4 (plenty of collaboration). Regional support is measured as the importance of regional actors for the development of the firm:

- Regional university

- Municipality Board

- Regional/County Board

- The largest firm in the region

- Regional competence center or business advisor

- Regional Chamber of Commerce or other business association

External knowledge concerns the geographic aspect, testing the importance of knowledge from different actors within and outside the own region:

- Own firm

- Intra-regional firms

- Extra-regional firms

- Intra-regional competence center and/or university

- Extra-regional competence center and/or university 
The categorical scales for regional support and external knowledge range from 0 (not important) to 4 (great importance).

Besides the variables regarding external support and collaboration we introduce several firm-level control variables:

- Size (no of employees)

- Share of employees with higher education

- Share of female employees

- Share of employees younger than 30

- Share of employees older than 60

- Family firm (yes/no)

- Geographic sales

- Region (base)

- Sweden (except own region)

- International

The number of employees controls for the size of the firm, since larger firms commonly have more resources to use in innovation activities (Smallbone et al. 2003). One such resource is the education of the employees, which is controlled for by the share of employees with higher education. Share of female employees as well as share of young/old employees control for the demographic structure of the firm, which may affect innovation through, for example, openness to various ideas. Family firms may operate toward other goals than growth and innovation, and family ownership may even hinder innovation potential (Chrisman et al. 2005). Firms that sell on the national and international market, as opposed to only the regional market, are exposed to more competition, which increases pressure on them to innovate in order to survive (Porter 1990).

In addition, we control for the total number of firms per square kilometer at the neighborhood level as well as in the labor market region. Firm density ${ }^{4}$ is a measure of economic activity and provides a control for various agglomeration economies. Firms located in denser regions and/or neighborhoods within regions may be more innovative due to benefits of matching, sharing, and learning (Duranton and Puga 2004). Descriptive statistics for all variables are presented in Online Resource 1.

\subsection{Estimated models}

As a first step, we estimate the relationships between innovation and external interaction using summated scales of the key variables. The seven innovation variables, the six collaboration variables, the six regional support variables, and the four external knowledge variables (own firm is excluded) are averaged to create one summated scale variable each for innovation, collaboration, regional support, and external knowledge. The minimum value for each variable is zero while the maximum value

\footnotetext{
${ }^{4}$ We have also tested both employee density and population density in the neighborhood and in the labor market region, with robust results.
} 
is four. The four summated scale variables comply with general rules of thumb. Item-to-test correlations exceed 0.5 and item-to-rest correlations exceed $0.3 .{ }^{5}$ Cronbachs' alpha exceeds 0.7 in all cases, ranging from 0.72 to 0.82 , which indicates reliability of the summative scales (Hair et al. 2010). These summated scale variables can be considered as continuous, which allows for linear estimation by ordinary least squares. The model specification is shown by Eq. 1 .

$$
\text { Innovation }_{i}=\alpha+\left[\text { External interaction }^{\prime} \gamma_{1}+[\text { Firm controls }]^{\prime} \gamma_{2}+[\text { Geographic controls }]^{\prime} \gamma_{3}+\varepsilon_{i}\right.
$$

in which the dependent variable is the averaged summated scale of innovation for firm $i$. The explanatory variables are categorized into three groups, where external interaction is a vector of the summated scales for collaboration, regional support, and external knowledge. Firm controls and geographic controls are described in the previous section, and $\varepsilon_{i}$ is the usual error term. To correct for spatial autocorrelation, for example, that innovation may be more common in certain regions, we apply robust standard errors clustered on labor market regions.

The main part of the analysis utilizes the full information in the dataset, with separate estimations on different forms of innovation, allowing for various types of external collaboration, support, and knowledge, and including control variables. Since the dependent variables are based on an ordinal scale, ordered logit estimation is a viable option for regression analysis. Ordered logit estimates the cumulative probability of being in one category versus all other. Following Williams (2006), the ordered logit model can be written as follows:

$$
P\left(Y_{i}>j\right)=\frac{\exp \left(X_{i k}^{\prime} \beta_{k}-\kappa_{j}\right)}{1+\left\{\exp \left(X_{i k}^{\prime} \beta_{k}-\kappa_{j}\right)\right\}}, j=0,1,2,3
$$

where $X$ is a vector of $k$ explanatory variables for firm $i, \beta_{k}$ a vector of the parameters to be estimated, $j$ represents the categories of the dependent variable (less one), and $\kappa_{j}$ are the cut points (which equal the negative of the constants). While these cut points vary with $j$, the $\beta$ 's do not, which implies an assumption (and restriction) that the influence of the independent variables are proportional across each category of the dependent variable, or in other words, that the distance between each category is proportional. When this proportional odds (or parallel lines) assumption is violated, which is commonly the case (Williams, 2006), standard errors are incorrect and parameter estimates are biased (Yatchew and Griliches 1985).

The Brant specification test (Brant 1990; Long and Freese 2006) shows that this assumption is indeed violated for many of the ordered logit estimations in the present case. In these cases, heterogeneous choice models (ordinal generalized linear models) are estimated as robustness tests, using heteroscedastic ordered logit estimation, which allows for dropping the proportionality constraint only for those variables that violate it. Hence, the $\beta$ parameters are estimated taking error variances, $\sigma_{i}$,

\footnotetext{
${ }^{5}$ But not 0.6 , which implies that they can enter estimations separately without causing problems with multicollinearity.
} 
into account. The heterogeneous choice model, in logit form, can thus be written as follows (Williams, 2010):

$$
P\left(y_{i}>j\right)=\frac{\exp \left(\frac{x_{i k}^{\prime} \beta_{k}-\kappa_{j}}{\sigma_{i}}\right)}{1+\left\{\exp \left(\frac{X_{i k}^{\prime} \beta_{k}-\kappa_{j}}{\sigma_{i}}\right)\right\}}, j=0,1,2,3 .
$$

If $\sigma_{i}=1$ for all observations, which is the case when there is no difference in error variances between categories, Eq. 3 collapses into the ordered logit model in Eq. ${ }^{6}{ }^{6}$

For both the ordered logit estimations and the heteroscedastic ordered logit estimations, the results are presented in terms of odds ratios. These provide a straightforward interpretation; if the odds ratio is greater than one, the relationship between the explanatory variable and the dependent variable is positive, while it is negative if the odds ratio is smaller than one. More specifically the interpretation is that the odds ratio shows how many times larger the odds for firms in categories greater than $m$ is than for firms in categories equal to or less than $m$, if the respective explanatory variable increases by one unit, keeping all other variables constant. Other possible approaches to estimate ordinal models that violate the proportionality assumption are multinomial logit models and generalized ordered logit models. Multinomial logit models are the least attractive in the present case since even though the distances between the categories of the dependent variables may be non-proportional, there is a clear ordering of the responses (ranging from no new products/services/ etc. to many new products/services/etc.). Regarding generalized ordered logit models, Williams (2010) argues that due to equal performance and relative simplicity, heterogeneous choice models may be preferred to generalized ordered logit models.

\section{Empirical results}

\subsection{A first look on the relationship between innovation and external interaction}

The estimated relationships between external engagement and innovation, both measured as summated scales, are presented in Table 1 . These results provide some first insights into the importance of promoting collaboration and external interactions and providing regional support to increase the innovativeness of small firms in the low-tech food industry, of which many are located in non-urban regions.

Table 1 shows that the relationship between collaboration, regional support, and external knowledge and innovation is highly significant and positive, even with the addition of control variables. An increase by one unit in either one of the averaged summated scale indices for external interaction is associated with an increase of between 0.16 and 0.18 in the averaged summated scale index for innovation. This

\footnotetext{
${ }^{6}$ See Williams (2010) for a more extensive explanation of heterogeneous choice models.
} 
Table 1 Estimated relationships between innovation and external support, knowledge, and collaboration

(1) Innovation (2) Innovation Innova-
tion

\begin{tabular}{|c|c|c|c|}
\hline Collaboration (summated) & $\begin{array}{l}0.2019 * * * \\
(0.0506)\end{array}$ & $\begin{array}{l}0.1937 * * * \\
(0.0510)\end{array}$ & $\begin{array}{l}0.1541 * * * \\
(0.0532)\end{array}$ \\
\hline Regional support (summated) & $\begin{array}{l}0.1868 * * * \\
(0.0630)\end{array}$ & $\begin{array}{l}0.1487 * * \\
(0.0646)\end{array}$ & $\begin{array}{l}0.1844 * * \\
(0.0704)\end{array}$ \\
\hline External knowledge (summated) & $\begin{array}{l}0.2084 * * * \\
(0.0531)\end{array}$ & $\begin{array}{l}0.1697 * * * \\
(0.0602)\end{array}$ & $\begin{array}{l}0.1852 * * * \\
(0.0620)\end{array}$ \\
\hline \multicolumn{4}{|l|}{ Firm controls } \\
\hline Size $(\ln )$ & & $\begin{array}{l}-0.0151 \\
(0.0564)\end{array}$ & $\begin{array}{l}-0.0136 \\
(0.0398)\end{array}$ \\
\hline Education & & $\begin{array}{l}0.0034 * * \\
(0.0016)\end{array}$ & $\begin{array}{l}0.0032 * \\
(0.0017)\end{array}$ \\
\hline Females & & $\begin{array}{l}0.0012 \\
(0.0017)\end{array}$ & $\begin{array}{l}0.0012 \\
(0.0017)\end{array}$ \\
\hline Young & & $\begin{array}{l}0.0028 \\
(0.0017)\end{array}$ & $\begin{array}{l}0.0030 * \\
(0.0017)\end{array}$ \\
\hline Old & & $\begin{array}{l}-0.0038^{*} \\
(0.0022)\end{array}$ & $\begin{array}{l}-0.0045^{*} \\
(0.0026)\end{array}$ \\
\hline Family firm & & $\begin{array}{l}-0.0807 \\
(0.0702)\end{array}$ & $\begin{array}{l}-0.0870 \\
(0.0694)\end{array}$ \\
\hline Sales Sweden & & $\begin{array}{l}0.3202 * * \\
(0.1280)\end{array}$ & $\begin{array}{l}0.2887 * * \\
(0.1317)\end{array}$ \\
\hline Sales international & & $\begin{array}{l}0.2792 * * \\
(0.1184)\end{array}$ & $\begin{array}{l}0.2637 * * \\
(0.1298)\end{array}$ \\
\hline \multicolumn{4}{|l|}{ Geographic controls } \\
\hline Neighborhood firm density (ln) & & & $\begin{array}{l}-0.0180 \\
(0.0209)\end{array}$ \\
\hline Regional firm density (ln) & & & $\begin{array}{l}0.0817 * * \\
(0.0356)\end{array}$ \\
\hline Constant & $\begin{array}{l}1.0234 * * * \\
(0.0683)\end{array}$ & $\begin{array}{l}0.8562 * * * \\
(0.1260)\end{array}$ & $\begin{array}{l}0.8388 * * * \\
(0.1203)\end{array}$ \\
\hline$F$-value & $30.67 * * *$ & $13.81 * * *$ & $9.04 * * *$ \\
\hline$R$-squared & 0.1414 & 0.1901 & 0.1936 \\
\hline Observations & 424 & 401 & 383 \\
\hline
\end{tabular}

Dependent variable: Innovation (averaged summated scale of all seven types of innovation) Ordinary Least Squares (OLS) estimations

*denotes significance at 10 percent level, ** denotes significance at 5 percent level, *** denotes significance at 1 percent level. Robust standard errors, clustered on labor market regions, in parentheses

implies that small food firms that are more engaged in collaboration with other firms in the region, that believe that they get support from actors within the region, and/or that use more external knowledge in their development of new goods and/or services are more innovative. These results broadly support much of the previous literature on the role of external knowledge and collaboration for innovation (Asheim et al. 2011; Porter 1990; Chesbrough 2003). 
Regarding the control variables, the innovativeness of firms is positively associated with the percentage of employees who have a higher education or are younger than 30 years. In contrast, firms with a larger share of employees above 60 years of age are less innovative. In addition, firms that sell on the national and international market, as opposed to only the regional market, have a higher degree of innovation. We find no agglomeration effect from the neighborhood, but firm density at the regional level is positively associated with innovation. This implies that firms in regions with more economic activity are more innovative, which may be due to better matching on the labor market, the sharing of resources, and/or learning through knowledge spillovers (Duranton and Puga 2004).

\subsection{Disentangling innovation and external interaction}

To disentangle innovation in small food firms, we measure innovation in the seven dimensions: new goods, new services, new processes, new markets, new suppliers, new ways of organization, and new ways of distribution. In addition, we look at the individual components of collaboration, regional support, and external knowledge.

Tables 2, 3, 4 present the results for the variables on external interaction from ordered logit estimations, including all control variables. ${ }^{7}$ If the Brant Chi-squared value is significant, we estimate heteroscedastic ordered logit models as robustness tests. The results from these estimations are presented in Online Resource 2 and commented on in case of non-robust results.

\subsubsection{Firm collaboration}

Table 2 provides the results for collaboration. Since collaboration refers to interaction with other firms, all forms of collaboration are examples of Doing, Using and Interacting (DUI) modes (Jensen et al. 2007; Dahl Fitjar and Rodríguez-Pose 2013). Table 2 shows that collaboration in at least one form with other firms in the region is positively significant for all types of innovation (besides new ways of organization). Among the different forms of collaboration, transports and sales seem to be most important. Collaboration regarding transports has a positive relationship with firm innovation in terms of new goods, services, processes, and markets, as well as new ways of distribution.

Except for new processes, the same types of innovations also benefit from collaboration regarding sales, which is also the case for using new suppliers. Collaboration regarding $R \& D$ is insignificant throughout. It may be that small food firms in general do not engage in pure $R \& D$ activities or that they do not perceive their collaboration with other firms as pure $R \& D$ activities, even though the result may be the development of new goods and/or services. Besides collaboration regarding sales and transports, collaboration regarding marketing is positively significant, albeit only for innovation in terms of new suppliers.

\footnotetext{
7 The results for the control variables are available in Online Resource 3.
} 


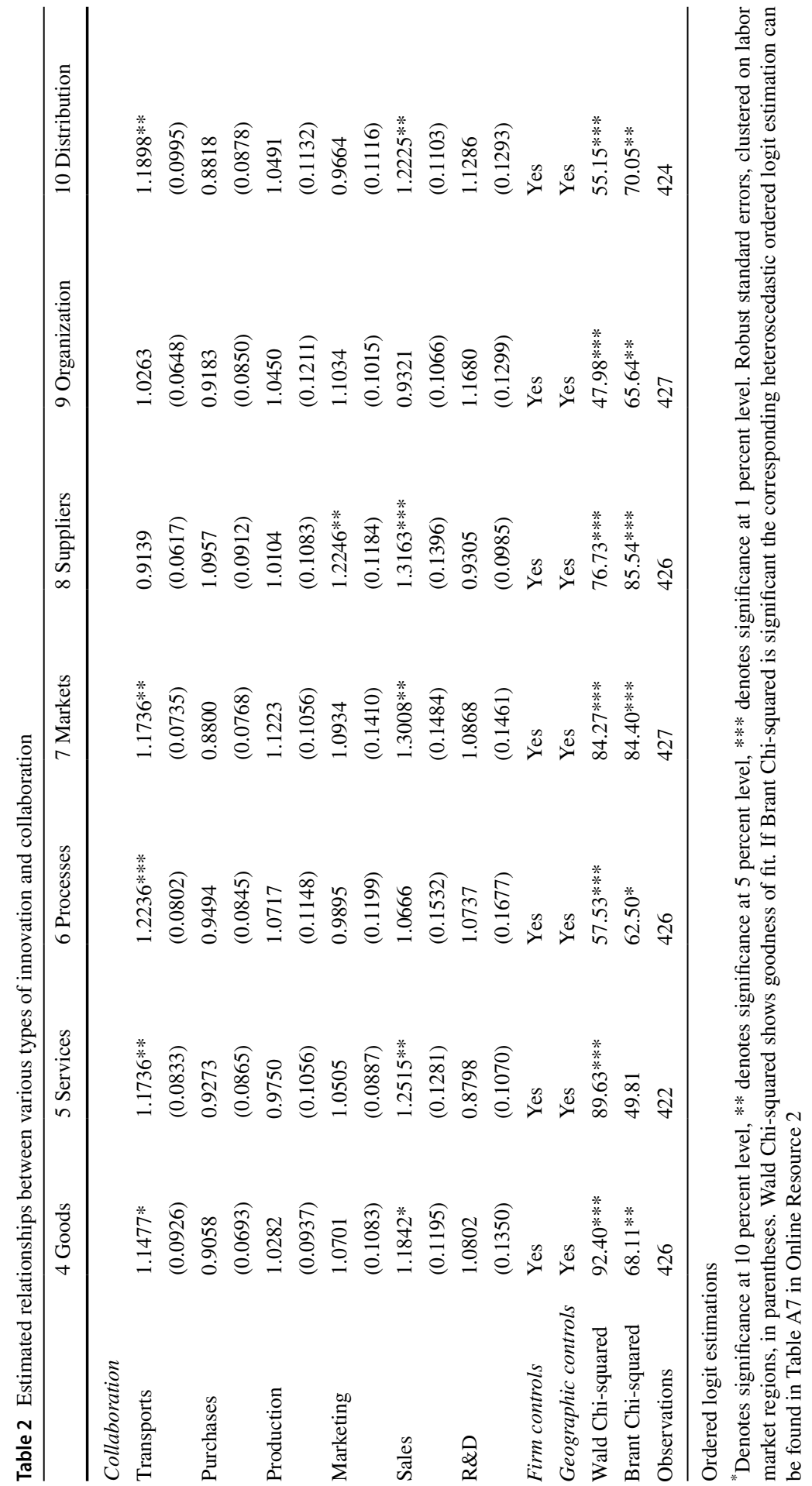




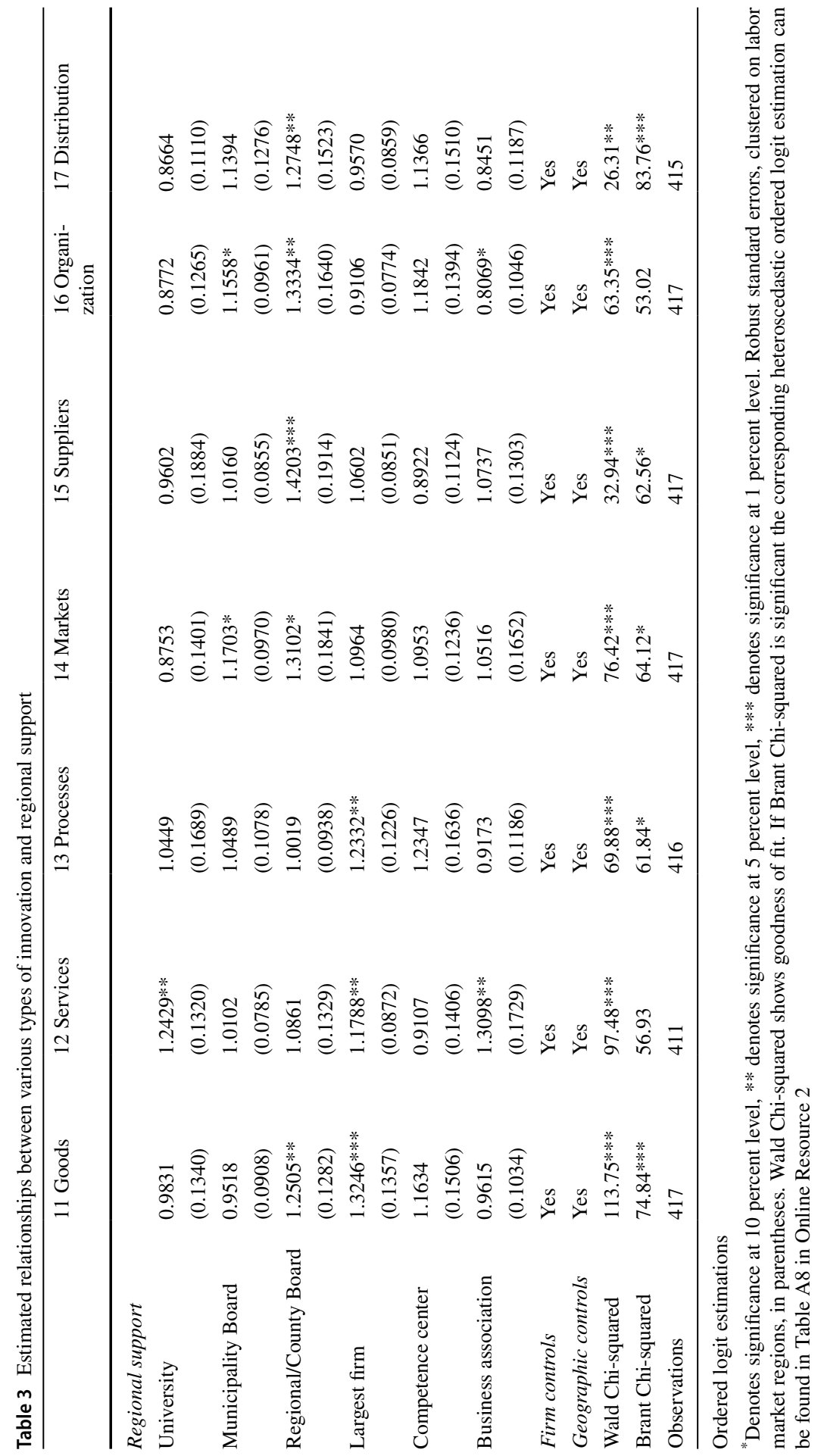




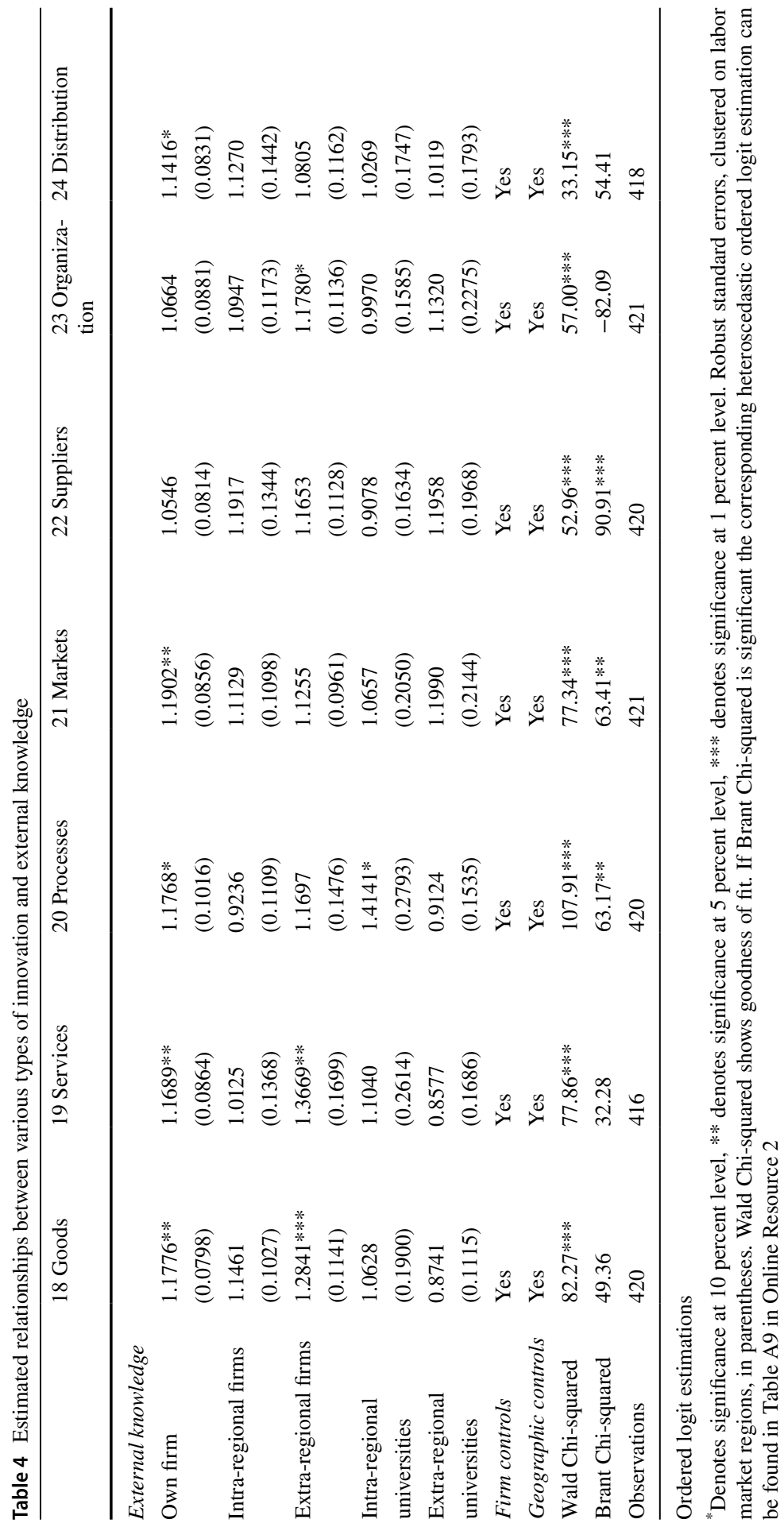




\subsubsection{Support from regional actors}

Table 3 provides the results for the importance of support from regional actors in the development of the firm. Support from the largest firm in the region appears to be positively related to innovation in terms of new goods, services, and processes, although the latter relationship turns insignificant in the heteroscedastic ordered logit estimation (see Table A8 in Online Resource 2). This is in line with previous studies on innovation in the food industry showing that external interaction with other firms is especially important for the traditionally recognized types of innovation (Stewart-Knox and Mitchell 2003; Gellynck and Kühne 2008; Capitanio et al. 2009). Regarding innovation beyond products and processes, the results show that small food firms benefit from support from the regional, county, and/or municipality board. In addition, goods innovation is positively related to support from a regional board. This indicates that political decisions and activities undertaken at these levels can influence firm innovation.

The results for new ways of distribution changes in the heteroscedastic ordered logit estimation (see Table A8 in Online Resource 2), from a positive relationship with support from a regional level to a positive relationship with support from the municipality level. In addition, in the heteroscedastic model, new processes and new ways of distribution benefit from support from regional competence centers and/or business advisors. Apart from support from the largest firm, innovation in terms of new services is positively related to support from a regional university, as well as from the regional chamber of commerce or other business association, all of which are Science, Technology and Innovation (STI) modes of interaction. The only negative relationships between innovation and an external interaction variable concern new ways of organization and new ways of distribution, which are both lower for firms that get more support from the regional chamber of commerce or other business association (for new ways of distribution, the estimate turns significant in the heteroscedastic ordered logit model).

\subsubsection{A geographic perspective on external knowledge}

Table 4 presents the estimation results for intra- and extra-regional external knowledge, as well as knowledge from the own firm. The results show that the higher firms value their own knowledge, the more innovative they are in all types of innovation except new suppliers and new organization. Following Dahl Fitjar and RodríguezPose (2013), external knowledge from other firms is considered as DUI modes of interaction, while knowledge from universities and research institutes are STI modes of interaction. Table 4 indicates that external knowledge from other firms is more important for innovation in small food firms than external knowledge from more research-based institutions. This supports previous research on innovation in the food industry (Stewart-Knox and Mitchell 2003; Gellynck and Kühne, 2008; Capitanio et al. 2009; Maietta et al. 2017; Karantininis et al. 2010) and may be due to cultural barriers and weak links between academia and business, especially concerning small- and medium-sized firms in remote locations (Tödtling and Kaufmann, 2001; Maietta 2015; Baycan and Stough 2013). Importantly, external knowledge 
is significant only for extra-regional firms, which is in line with Dahl Fitjar and Rodríguez-Pose (2013) and Bjerke and Johansson (2015). This implies that it is the knowledge networks that extend beyond the own region that matter for innovation in small food firms. Finally, external knowledge seems to be valuable primarily for traditionally recognized types of innovation, that is, new goods and services, although it is also weakly significant for new ways of organization.

Innovation in terms of new processes is the only type of innovation positively related to an STI mode of external interaction, that is, support/knowledge from universities and/or research institutes. As opposed to external knowledge from other firms, it is intra-regional universities and/or research institutes that matter for new processes. This may be explained by that the cultural barriers and weak links between academia and business are being partly overcome by geographic proximity. Indeed, many universities in Sweden have a regional focus and interact with businesses in their own region, for example, through cooperation on student field project work and theses.

\section{Conclusions}

The ability of firms to renew themselves is becoming increasingly important from the perspective of firm survival and growth (Audretsch and Mahmood 1995; Cefis and Marsili 2005). Renewal and technological change are also particularly important for firms that operate in the food industry. The competition for product differentiation, the increasingly global character of food markets, higher requirements on food safety, and advances in biotechnology have all made innovation a necessity rather than an option for the survival and growth of small food firms (Triguero et al. 2013).

In this paper, we have disentangled innovation in small and specialized food firms by distinguishing between various types of innovation beyond the usual classification of new products. We argue that this is necessary to capture the full innovation potential of firms with low capital intensity and low orientation toward research and development, which is the case for many small and specialized producers in the low-tech food industry, especially those located in rural regions. Since smalland medium-sized firms commonly have limited internal knowledge and financial resources, the focus of the paper is on the relationship between external interaction and firm innovation. External interaction is measured in terms of either collaboration with other firms in the region, support from regional actors in the development of the firm, or the application of intra- and extra-regional external knowledge in innovation activities.

From the results, we can conclude that there is a positive relationship between firm innovation and external interaction for small food producers in Sweden. In particular, collaboration regarding transports and sales enhances most types of innovation. However, our results also show that the relationship differs across the various dimensions of external interaction and innovation. More conventional forms of firm innovation, new goods and services, benefit from external knowledge from extra-regional firms as well as regional support from the largest firm. Other types of innovation, such as selling into new markets, use of new suppliers, new ways 
of organization, and new distribution channels, increase mostly from support from regional and municipality boards. On the other hand, we find little support for a positive relationship between firm innovation and links to universities and/or research institutes. Such links are probably rare for the food firms in our sample, as they tend to be both small and remotely located and operate in a low-tech sector.

It has become almost a mantra that collaboration is a key factor for successful innovation activities. Our study strengthens this thesis and suggests that local and regional policy makers can influence firm innovation by promoting collaboration and knowledge networks between firms, in particular, by providing support to small firms that operate in low-tech sectors and are located in rural regions, as these firms often lack skilled labor and financial resources. Additionally, this study shows the importance of extra-regional connections for innovation in the food industry. Our findings indicate that small and rural firms can compensate for lower accessibility and other disadvantages that firms located outside metropolitan regions face by having specialized links to selected extra-regional partners. These links probably have higher establishment and maintenance costs than corresponding partner links in metropolitan regions, providing a strong argument for supporting this kind of network building for small, rural firms.

From a more general view, the fact that different factors seem to have impacts on the various types of innovation calls for innovation policies and strategies flexible enough to enable "tailor-made" solutions at the local level. Firm management, policy makers, and practitioners need to consider the local context, regarding the prerequisites of local firms and the conditions offered by the local economic milieu. To conclude the paper, we refer to Roger Stough (2010), who argued that (local) leadership, with local knowledge, is one of the key elements to achieve regional economic development. Our results support using this type of leadership to promote collaboration and knowledge networks of small firms in low-technology and/or rural settings.

Supplementary Information The online version contains supplementary material available at https://oi. org/10.1007/s00168-021-01087-6.

Funding Open access funding provided by Jönköping University. This paper has been produced within the EU-RURAGRI project "Towards a smart rural Europe" (TASTE), of which the Swedish part is financed by the research council Formas, grant 2013-276.

\section{Declarations}

Conflicts of interest The authors declared that there are no conflicts of interest.

Data availability The data can be made available upon request.

Code availability The STATA code can be made available upon request.

Open Access This article is licensed under a Creative Commons Attribution 4.0 International License, which permits use, sharing, adaptation, distribution and reproduction in any medium or format, as long as you give appropriate credit to the original author(s) and the source, provide a link to the Creative Commons licence, and indicate if changes were made. The images or other third party material in this article are included in the article's Creative Commons licence, unless indicated otherwise in a credit line to the material. If material is not included in the article's Creative Commons licence and your intended use is 
not permitted by statutory regulation or exceeds the permitted use, you will need to obtain permission directly from the copyright holder. To view a copy of this licence, visit http://creativecommons.org/licen ses/by/4.0/.

\section{References}

Andersson M, Larsson JP, Klaesson J (2014) The sources of the urban wage premium by worker skills: spatial sorting or agglomeration economies? Pap Reg Sci 93(4):727-747

Arrow KJ (1962) The economic implications of learning by doing. Rev Econ Stud 29(3):155-173

Asheim BT, Smith HL, Oughton C (2011) Regional innovation systems: theory, empirics and policy. Reg Stud 45(7):875-891

Audretsch DB, Mahmood T (1995) New firm survival: new results using a hazard function. Rev Econ Stat 77(1):97-103

Baycan T, Stough RR (2013) Bridging knowledge to commercialization: the good, the bad, and the challenging. Ann Reg Sci 50(2):367-405

Baycan T, Nijkamp P, Stough R (2017) Spatial spillovers revisited: innovation, human capital and local dynamics. Int J Urban Reg Res 41(6):962-975

Bjerke L, Johansson S (2015) Patterns of innovation and collaboration in small and large firms. Ann Reg Sci 55(1):221-247

Brant R (1990) Assessing proportionality in the proportional odds model for ordinal logistic regression. Biometrics 46(4):1171-1178

Bresciani S (2017) Open, networked and dynamic innovation in the food and beverage industry. British Food Journal 119(11):2290-2293

Caloghirou Y, Kastelli I, Tsakanikas A (2004) Internal capabilities and external knowledge sources: complements or substitutes for innovative performance? Technovation 24(1):29-39

Capitanio F, Coppola A, Pascucci S (2009) Indications for drivers of innovation in the food sector. British Food J 111(8):820-838

Cefis E, Marsili O (2005) A matter of life and death: innovation and firm survival. Ind Corp Chang 14(6):1167-1192

Chesbrough HW (2003) The era of open innovation. MIT Sloan Manag Rev 44(3):35-41

Chrisman JJ, Chua JH, Sharma P (2005) Trends and directions in the development of a strategic management theory of the family firm. Entrep Theory Pract 29(5):555-576

Cooke P, Morgan K. (1998) The creative milieu: a regional perspective on innovation. In: Dodgson M and Rothwell R (eds) The Handbook of Industrial Innovation. Cheltenham: Edward Elgar.

Cumbers A, Mackinnon D, Chapman K (2003) Innovation, collaboration, and learning in regional clusters: a study of SMEs in the Aberdeen oil complex. Environ Plan A 35(9):1689-1706

Dahl Fitjar R, Rodríguez-Pose A (2013) Firm collaboration and modes of innovation in Norway. Res Policy 42(1):128-138

de Jong JPJ, Vermeulen PAM (2006) Determinants of product innovation in small firms: a comparison across industries. Int Small Bus J 24(6):587-609

Dillman DA, Smyth JD, Christian LM (2014) Internet, phone, mail, and mixed-mode surveys: the tailored design method. Wiley, Hoboken

Duranton G, Puga D (2004) Micro-foundations of urban agglomeration economies. In: Henderson JV, Thisse J-F (eds) Handbook of Regional and Urban Economics, Volume 4: Cities and Geography. Elsevier, Amsterdam, pp 2063-2117

Edwards T, Delbridge R, Munday M (2005) Understanding innovation in small and medium-sized enterprises: a process manifest. Technovation 25(10):1119-1127

Edwards P, Sengupta S, Tsai C-J (2009) Managing low-skill workers: a study of small UK food manufacturing firms. Hum Resour Manag J 19(1):40-58

Everett S (2008) Beyond the visual gaze? The pursuit of an embodied experience through food tourism. Tour Stud 8(3):337-358

Feldman M (1994) Knowledge complementarity and innovation. Small Bus Econ 6(5):363-372

Foray D (2016) On the policy space of smart specialization strategies. Eur Plan Stud 24(8):1428-1437

Freel MS (2000) Barriers to product innovation in small manufacturing firms. Int Small Bus J 18(2):60-80 
Galeti F, Bigliardi B, Petroni A (2016) Open innovation in food firms: Implementation strategies, drivers and enabling factors. Int J Innov Manag 20(03):1650042

Gellynck X, Kühne B (2008) Innovation and collaboration in traditional food chain networks. Journal on Chain and Network Science 8(2):121-129

Hair JF, Black WC, Babin BJ, Anderson RE (2010) Multivariate data analysis: a global perspective. Pearson Education, London

Jensen MB, Johnson B, Lorenz E, Lundvall BÅ (2007) Forms of knowledge and modes of innovation. Res Policy 36(5):680-693

Karantininis K, Sauer J, Furtan WH (2010) Innovation and integration in the agri-food industry. Food Policy 35(2):112-120

Karlsson C, Johansson B, Kobayashi K and Stough RR. (2014) Knowledge, innovation and space: Introduction. Knowledge, Innovation and Space. Cheltenham: Edward Elgar Publishing.

Lee S, Park G, Yoon B, Park J (2010) Open innovation in SMEs-An intermediated network model. Res Policy 39(2):290-300

Lefebvre VM, De Steur H and Gellynck X. (2015) External sources for innovation in food SMEs. British Food Journal.

Long JS, Freese J (2006) Regression models for categorical dependent variables using stata. Stata Press, College Station, TX

Lundvall B-A (1992) National systems of innovation: Toward a theory of innovation and interactive learning. Pinter, London

Maietta OW (2015) Determinants of university-firm R\&D collaboration and its impact on innovation: a perspective from a low-tech industry. Res Policy 44(7):1341-1359

Maietta OW, Barra C, Zotti R (2017) Innovation and university-firm R\&D collaboration in the european food and drink industry. J Agric Econ 68(3):749-780

Marshall A (1890) Principles of economics. Macmillan, London, UK

McAdam M, McAdam R, Dunn A, McCall C (2014) Development of small and medium-sized enterprise horizontal innovation networks: UK agri-food sector study. Int Small Bus J 32(7):830-853

McKelvey M, Ljungberg D (2017) How public policy can stimulate the capabilities of firms to innovate in a traditional industry through academic engagement: the case of the Swedish food industry. R\&D Management 47(4):534-544

Naldi L, Nilsson P, Westlund H, Wixe S (2015) What is smart rural development? J Rural Stud 40:90-101

Nelson P (1970) Information and consumer behavior. J Polit Econ 78(2):311-329

Nieto MJ, Santamaría L (2010) Technological collaboration: bridging the innovation gap between small and large firms. J Small Bus Manage 48(1):44-69

Nijkamp P, Stough R, de Noronha Vaz MT (2007) Local knowledge and innovation policy. Env Plan Gov Policy. https://doi.org/10.1068/c2505ed

Porter ME (1990) The competitive advantage of nations. Macmillan, London, UK

Rothwell R (1991) External networking and innovation in small and medium-sized manufacturing firms in Europe. Technovation 11(2):93-112

Schumpeter JA (1934) The theory of economic development: an inquiry into profits, capital, credit, interest, and the business cycle. Harvard University Press, Cambridge, MA

Sims R (2009) Food, place and authenticity: local food and the sustainable tourism experience. J Sustain Tour 17(3):321-336

Smallbone D, North D and Vickers I. (2003) The role and characteristics of SMEs in innovation. In: Asheim BT, Isaksen A, Nauwelaers C, et al. (eds) Regional Innovation Policy for Small-Medium Enterprises. Cheltenham: Edward Elgar.

Spithoven A, Vanhaverbeke W, Roijakkers N (2013) Open innovation practices in SMEs and large enterprises. Small Bus Econ 41(3):537-562

Stewart-Knox B, Mitchell P (2003) What separates the winners from the losers in new food product development? Trends Food Sci Technol 14(1-2):58-64

Stimson RJ, Stough RR, Salazar M (2009) Leadership and institutions in regional endogenous development. Edward Elgar Publishing, Cheltenham

Stimson RJ, Stough RR, Salazar M. (2005) Leadership and institutional factors in endogenous regional economic development. Investigaciones Regionales-Journal of Regional Research 7): 23-52.

Stough RR (2003) Strategic management of places and policy. Ann Reg Sci 37(2):179-201

Stough RR (2010) Leadership and creativity in regional economic development. Eur Plan Stud 18(4):613-627 
Tödtling F, Kaufmann A (2001) The role of the region for innovation activities of SMEs. Europ Urb Reg Stud 8(3):203-215

Tödtling F, Trippl M (2005) One size fits all? Towards a differentiated regional innovation policy approach. Res Policy 34(8):1203-1219

Triguero A, Moreno-Mondéjar L, Davia MA (2013) Drivers of different types of eco-innovation in European SMEs. Ecol Econ. https://doi.org/10.1016/j.ecolecon.2013.04.009

Verbeke W (2005) Agriculture and the food industry in the information age. Eur Rev Agric Econ 32(3):347-368

Vrontis D, Thrassou A, Santoro G, Papa A (2017) Ambidexterity, external knowledge and performance in knowledge-intensive firms. J Technol Transf 42(2):374-388

Williams R (2006) Generalized ordered logit/partial proportional odds models for ordinal dependent variables. Stata J 6(1):58-82

Williams R (2010) Fitting heterogeneous choice models with oglm. Stata J 10(4):540-567

Yatchew A, Griliches Z (1985) Specification error in probit models. Rev Econ Stat. https://doi.org/10. 2307/1928444

Zeng SX, Xie XM, Tam CM (2010) Relationship between cooperation networks and innovation performance of SMEs. Technovation 30(3):181-194

Publisher's Note Springer Nature remains neutral with regard to jurisdictional claims in published maps and institutional affiliations. 